\title{
ECOLOGICAL FACTORS AFFECTING EFFICIENCY AND HEALTH IN WARSHIPS*
}

\author{
BY \\ F. P. ELLIS $\dagger$ \\ (RECEIVED FOR PUBLICATION JANUARY 18, 1960)
}

The environment of those who live and work in warships is closely related to the way the ships are built and employed. In stating the requirements for the atmosphere between decks the emphasis has swung during the past 50 years from the need for controlling the chemical constituents to the control of the factors which comprise the thermal environment, and now, with the advent of the nuclear-powered submarine, to the need for achieving, as nearly as possible, complete physical, chemical, and microbiological control.

Between 1944 and 1953 the thermal factors between decks were investigated in a series of studies carried out in H.M. Ships. The average effective temperatures on the mess decks and in the work places of 11 ships in the Eastern Fleet in 1944 exceeded $84^{\circ} \mathrm{F}$. $\left(28.9^{\circ} \mathrm{C}\right.$.). In compartments where radiant heat was an added factor the average corrected effective temperature levels were $1^{\circ}$ or $2^{\circ} \mathrm{F}$. $\left(0 \cdot 55-1 \cdot 1^{\circ} \mathrm{C}\right.$.) higher than the corresponding effective temperatures.

The effects of climatic conditions on naval personnel were investigated by psychological studies to determine the levels of warmth at which performance deteriorated; by physiological experiments to show the levels of warmth at which the collapse of men working at different work rates might be expected; by comfort surveys in ships and on shore to determine the levels of warmth at which the majority enjoyed optimum comfort; and by relating the monthly incidence of the common causes of ill-health to the average monthly upper-deck temperature as recorded at noon each day in order to determine the temperature level above which sickness increased. It was concluded that the upper desirable level of warmth to consider when designing ships for hot climates was an effective temperature of $78^{\circ} \mathrm{F} .\left(25 \cdot 5^{\circ} \mathrm{C}\right.$.).

As it is usually impracticable in many compartments to achieve temperatures below $78^{\circ} \mathrm{F}$. $\left(25.5^{\circ} \mathrm{C}\right.$.) in the tropics without the generous application of air cooling, attention was then directed to the associated effects on the chemical and bacterial constituents of restricting air supplies, an unavoidable feature of most air conditioning systems, and to defining the permissible lower limits for fresh air requirements.

The nuclear submarine with its capacity for remaining submerged for very long periods raises new problems relating to life in a confined space and involving very prolonged exposure to the submarine environment. These problems have still to be investigated.

The factors which are necessary to provide warships' companies with an equable environment in which to live and work can be discussed conveniently if we keep in mind the changing emphasis which has guided policy in recent times. Until about 400 years ago, or even after that time, men tended to live on ships rather than in them. Sir Walter Raleigh made the terse comment "cabins are but sluttish dens that breed sickness" (Shaw,

* A paper read to the Eighth Annual Medical Conference of North Atlantic Treaty Nations at the Supreme Headquarters Allied Powers, Europe. Paris, April 8-10, 1959.

t Surgeon Captain, Royal Navy.
1929); and the despatches of the Lord High Admiral of the English Fleet, Howard of Effingham, contain ample evidence that the hygienic state of the ships which awaited the onslaught of the Spanish Armada in $\mathbf{1 5 8 8}$ was truly deplorable. After the Tudor period the main improvements were to keep ships and ships' companies clean by scrubbing decks, washing clothing (the issue of soap was a revolutionary advance), by issuing clean clothing, by isolating the sick, and by employing wind sails, wind scoops, and other devices to convey air below.

The most notable devices were the "blowing wheel" of Desaguliers worked by men whom he 318 
called "ventilators", with which he first ventilated the House of Commons early in the eighteenth century (Desaguliers, $1727 ; 1735$ ), the hand-worked bellows devised shortly afterwards by the country clergyman and biologist Stephen Hales (ClarkKennedy, 1929; Hales, 1755) and convection pipes leading from ships' galley fires which were invented by a brewer, Samuel Sutton (Bernan, 1845). It is a sombre thought that these developments were motivated not only by the need for keeping mariners in fighting trim, but also by the requirement of the merchants of the slave trade between the Guinea Coast and the plantations in the Americas to preserve their human cargoes in a saleable condition. All these methods had their successes in the Navy, but only in the face of hidebound conservatism. Thus Sutton drolly remarked (Bernan, 1845) "I particularly remember that, being at a coffee house near the Admiralty, I placed myself nigh some gentlemen of the Navy and enquired of them, as I had before of others, as to the usefulness of a change of air: all, to a man, acknowledged it would be of the utmost service. I told them I could procure it; upon which one of the company went to another table, and the rest followed him; and I heard him tell the others that he heartily pitied me as being really mad and out of my senses". One does not read much about the thermal environment in the journals of those days, for infectious disease and nutritional deficiencies swamped nearly all other considerations of medical importance. In addition, the wooden sailing ships did not generate the vast quantities of heat which must be dissipated from ships propelled by power plants.

When it became possible to supply air with powerdriven fans in the latter half of the nineteenth century it was not therefore surprising that interest centred at first on preserving the chemical composition of the atmosphere near to that of atmospheric air about which a great deal had been learnt in the previous 100 years. It was required of the designer that the ventilation arrangements should maintain the proportion of carbon dioxide in the air below $0.06 \%$, only $0.02 \%$ in excess of the proportion in the outside air. Even in 1914, when an Admiralty Ventilation Committee (1914) reported, this exacting requirement was only relaxed to $0.07 \%$. By this time, however, a new factor was already making itself felt, namely, excessive environmental warmth, an undesirable waste product of the ever more powerful propulsion machinery. This factor became increasingly prominent during the First World War, which was fought mostly in northerly or temperate waters. The situation was aggravated in the years that followed by the addition of more and more defensive and offensive equipment, which called for increased generating power, and the need for even greater propulsive power, and which together led to a corresponding increase in what came to be called "wild heat". When, therefore, in 1938 another Admiralty Ventilation Committee (1938) rendered its Report, the carbon dioxide criterion was abandoned. New standards, which aimed at the control of compartment warmth rather than chemical purity of air, were accepted. An air temperature of $15 \cdot 5-18 \cdot 3^{\circ} \mathrm{C}$. was recommended for cold climates and the requirements in tropical or sub-tropical waters were not discussed in detail. "Air-conditioning", or air-cooling, was not considered essential.

Events in the second world war soon proved that submarines could not carry out repeated war patrols in the tropics without air-cooling machinery and towards the end of the war British submarines operating in tropical waters were effectively air conditioned-a convincing demonstration of the primary importance of providing adequate means for controlling the full ranges of conditions likely to be encountered in warfare under environmental extremes. Strongly worded reports from the Commanders-in-Chief of the relatively small British forces which were at first maintained in the East also stressed the difficulties of preserving the health and efficiency of the crowded ships' companies of surface ships, as well as submarines. This was brought home in 1943 and 1944 when the greater part of the British Fleet, hitherto occupied in more temperate waters, began to congregate in the Indian Ocean. There were serious misgivings as to whether the ships could remain closed up during a prolonged action without crippling loss of fighting efficiency. These doubts were never really answered, for the atomic bomb stopped the war before any further conventional battle fleet action in the grand style (as opposed to aircraft carrier action) could be fought in the tropics. When hard work had to be done heat stress did not only raise problems in tropical climates. The rate of fire was limited in temperate or even in northern waters by the effects of heat stress on the gun turret crews.

Early in 1944 at the request of the Admiralty a sub-committee was appointed by the Medical Research Council's Royal Naval Personnel Research Committee to examine the effects of climate and other environmental factors on fighting efficiency. This sub-committee commenced its task handicapped by an incomplete knowledge not only of the conditions in the Fleet, but also by a lack of information concerning the levels of warmth which might be expected to impair physiological or psychological efficiency, health or comfort. Such knowledge as was available had mostly been obtained in 
emperate climates, and the views of the experts varied widely on whether or not this could be applied to men who would be partially or completely acclimatized to air temperatures far in excess of those at which workers in hot industries in temperate climates lived when they were not at work.

The five-pronged attack on the tropical problem which followed was ambitious and, although it was surprising how much it was possible to contribute to the practical problems of the day, it was only gaining momentum by the time the war ended. The first group of investigators measured the climatic conditions between decks in action and when cruising in the Eastern and British Pacific Fleets, and evaluated the effects on the men. The second group, at the National Hospital for Nervous Diseases, Queen Square, London studied the physiological effects of hard work, such as guns' crews had to perform, on men wearing action working dress during four-hour watches at high temperatures. The third group, in the Psychology Department at the University of Cambridge, examined the effects of various levels of warmth on the performance of naval ratings carrying out tests which were based on the semi-skilled activities of wireless telegraphy or radar operators, or men carrying out manual tracking tasks in weapon control systems. These physiological and psychological studies were essentially exploratory studies, on men who were "artificially acclimatized" by repeated daily exposure to work at high temperatures, designed to develop techniques which could be applied later to "naturally acclimatized" men in the tropics. The tropical phase of the work was delayed until 1948. A well-equipped Climatic Laboratory was established by then in the grounds of the King Edward VII Medical College, Singapore and laboratory studies were continued there until 1953. The fourth approach was to relate sensations of thermal comfort to temperature, humidity, and air movement conditions in living spaces or offices in ships and on shore with a view to identifying the levels of warmth at which most individuals thought they were thermally "comfortable" rather than "too warm" or "too cool", and those at which perceptible sweating commenced. In the fifth series of investigations the sickness rates were compared in ships and on shore in the tropics and in ships operating in temperate and in tropical climates. The monthly rates, as determined from figures reported weekly by all ships of the Fleet, were related to the average monthly upper-deck temperature recorded at noon each day between 1948 and 1952, to show the levels of ambient air temperature at which there was evidence of increasing ill-health.

It is necessary to discuss briefly the methods which can be employed for measuring warmth. The factors to be considered were the air temperature, humidity, air speed, the mean radiant temperature of the surroundings, the work rate, and clothing.

The methods of measurement shown in Table 1 were evolved either from comfort studies (1), (2) or physiological studies (3) in climatic laboratories, or as a result of evaluation in the field of the conditions under which men were found to collapse under training or during operations (4). The effective temperature scales, developed by Yaglogou, Houghten, and their colleagues (Houghten and Yaglogou, 1923, 1924; Yaglogou and Miller, 1925), for the American Society of Heating and Ventilating Engineers over 30 years ago and adopted by the United States Navy, were chosen as the most convenient method for use in the Royal Navy during the war.

\section{TABLE 1}

(1) EFFECTIVE TEMPERATURE-derived by applying the dry-bulb and wet-bulb temperatures and air speed to a "basic" chart for persons stripped to the waist or a "normal" chart for light clothing. For evaluating the conditions conducive to comfort indoors of sedentary or lightly occupied persons in compartments where radiant heat is not a factor. (Used in Royal Navy and U.S. Navy.)

(2) “CORRECTED" EFFECTIVE TEMPERATURE (BASIC OR NORMAL)derived by applying the globe and wet-bulb temperatures and air speed to the same charts. For compartments where radiant heat is a prominent factor. (Used in Royal Navy.)

(3) PREDICTED FOUR-HOUR SWEAT RATE (P4SR)-derived by applying dry-bulb, wet-bulb and globe thermometer temperatures, air speed, work rate and an estimate of the amount of clothing worn to the P4SR nomogram. For evaluating the stress imposed by warm climates with varying work rates.

(4) WET-BULB GLOBE THERMOMETER INDEX (WBGT)-derived from 0.7 of wet-bulb temperature (in sun and wind) +0.2 of globe temperature (in sun and wind) $+\mathbf{0 . 1}$ of dry-bulb temperature (shade). For defining conditions outdoors which call for modification of training programmes. (Recommended for U.S. Armed Forces.)

There are two scales or charts, "basic" and "normal", which relate to sedentary persons stripped to the waist or clad in light indoor clothing. The "effective" temperature is "the temperature of still air saturated by water vapour in which an equivalent sensation of warmth (to that experienced at the air temperature, humidity and air speed under investigation) would be experienced by the average individual". For example, according to the "normal" chart, with an air temperature of $26 \cdot 7^{\circ} \mathrm{C}$. a wet-bulb temperature of $26.7^{\circ} \mathrm{C}$., and an air speed of $20 \mathrm{ft}$. per min. (virtually still air) the effective temperature is $26.7^{\circ} \mathrm{C}$. But, also, with an air temperature of $35^{\circ} \mathrm{C}$., a wet-bulb temperature of $21^{\circ} \mathrm{C}$. and an air speed of $200 \mathrm{ft}$. per min. the effective temperature is still $26.7^{\circ} \mathrm{C}$.; that is to say a man would be equally comfortable in either environment. These charts were constructed to indicate the effects on comfort of variations in air temperature, humidity and air movement only. To allow for radiant 
heat, when necessary, it was recommended by Bedford (1946) that the readings of Vernon's black globe thermometer be employed in place of those of the dry-bulb thermometer when the charts were used, to give a "corrected effective temperature". It was stated that effective temperatures (corrected, normal, or basic) of $26.7^{\circ} \mathrm{C}$. should not be exceeded in the tropics and that when $30^{\circ} \mathrm{C}$. was exceeded some loss of efficiency, discomfort or ill-health would have to be accepted.

An important omission from the effective temperature charts, was that there was no correction for work rate. This was partially overcome by a stratagem devised at the National Hospital by Dr. Brian McArdle and his colleagues (McArdle, Dunham, Holling, Ladell, Scott, Thomson, and Weiner, 1947; Smith, 1955). From a rather more complicated and empirical nomogram, constructed from their experimental data, the "predicted four-hour sweat rate", or the "P4SR" to which this rather cumbersome term was abbreviated, can be determined. In their view an index based mainly on the sweat rate provides the best guide to the stress imposed by different hot environments, and this has provided the basis for the development of further new indices, notably that introduced by Belding and Hatch (1955) to which there is not space to refer further here. "P4SR values" can be obtained from this nomogram, provided the dry-bulb, wet-bulb and globe temperatures, the air speed, the energy cost of the activity under investigation, and the clothing worn are known.

One other stress index, recently introduced in the United States of America, should be mentioned, the "WBGT Index" or the "wet-bulb globe-thermometer index". The "WBGT" is obtained from the sum of 0.7 of the wet-bulb temperature exposed to sun and wind, 0.2 of the globe thermometer temperature similarly exposed and $0 \cdot 1$ of the dry-bulb temperature in the shade. Guidance is given in United States Army Technical Bulletin, Medical 175 and corresponding United States Navy and Air Force Instructions (United States Army, 1957) for its use in limiting training procedures during hot weather. It is more simple to use than effective temperature, especially if observers are not fully trained. A useful by-product of its acceptance trials was that it was found that Bedford's corrected effective temperature could be used for forecasting conditions likely to cause incapacitation out of doors as well as indoors or between decks and that it was at least as reliable as the WBGT Index when used in this way (Minard, 1958).

The findings of these studies in terms of effective temperature and predicted four-hour sweat rate were the subject of numerous domestic reports to the Medical Research Council's Royal Naval Personnel Research Committee and were summarized in a series of review papers and lectures as they became available (Critchley, 1945; Ellis, 1947, $1948 ; 11950 ; 1953 a ; 11954$; 1955). The psychological studies in England were published by Mackworth (1950; 1948). The psychological studies at Singapore have been summarized in reports to the Royal Naval Personnel Research Committee and published by Pepler (1953, 1954 and 1958). A compilation of the principal reports in the physiological series is being prepared for publication by the Medical Research Council and should be available in 1960. Points of naval interest were as follows:

1. The average effective temperatures on the mess decks and in the work places of 11 ships of the Eastern Fleet, shown in Table 2, were always in excess of the recommended $26.7^{\circ} \mathrm{C}$. and frequently exceeded the "upper tolerable level" of $30^{\circ} \mathrm{C}$.

In those compartments where radiant warmth was an added factor, and in which globe thermometer measurements were made, the situation was even less satisfactory (Table 3 ), although the added stress due to this factor was not as great as was expected before the survey was undertaken, except perhaps in galleys.

These average effective temperatures, for which the warship designer must cater when he makes provision for climate control at the upper end of the temperature scale, may be kept in mind as the evidence concerning the effects of warmth on personnel is reviewed.

2. According to the psychological tests sedentary watchkeepers, stripped to the waist and engaged on semi-automatic semi-skilled work, such as morse code reception, are less efficient when the basic effective temperature is somewhere between $27 \cdot 2^{\circ} \mathrm{C}$. and $30^{\circ} \mathrm{C}$. provided they are "naturally" (Pepler, 1953, 1954, 1958) or "artificially" (Mackworth, $1950,1948)$ acclimatized to working at this level of warmth. The normal effective temperatures for men wearing naval working dress would be distinctly lower (probably of the order of 0.55 or $1.1{ }^{\circ} \mathrm{C}$. or perhaps even more). Unacclimatized men were not studied.

3. The physiological studies indicated that, under the highly artificial conditions of these experiments, some fit and trained young men may be incapacitated when the environmental conditions are such that the "P4SR" value would exceed 4.5, again provided that they were either "naturally" or "artificially" acclimatized to working under the conditions in question, whether they were living in the tropics or in a temperate climate when they were not at work (Irwin, 1956; McArdle et al., 1947). Dry- and wet- 
TABLE 2

AVERAGE NORMAL EFFECTIVE TEMPERATURES IN 11 SHIPS OF THE EASTERN FLEET, 1944

\begin{tabular}{|c|c|c|c|c|c|}
\hline Compartment & $\begin{array}{c}\text { Normal Effective } \\
\text { Temperature } \\
\left.\text { ( }{ }^{\circ} \mathbf{C} .\right)\end{array}$ & $\begin{array}{c}\text { Dry-bulb } \\
\text { Temperature } \\
\left.\text { ( }{ }^{\circ} \mathbf{C} .\right)\end{array}$ & $\begin{array}{c}\text { Wet-bulb } \\
\text { Temperature } \\
\text { ( }{ }^{\circ} \text { C.) }\end{array}$ & $\begin{array}{l}\text { Air Speed } \\
\text { (ft./min.) }\end{array}$ & $\begin{array}{c}\text { No. of } \\
\text { Observations }\end{array}$ \\
\hline $\begin{array}{l}\text { Mess decks (living spaces) } \\
\text { Machinery spaces } \\
\text { Gunnery control positions } \\
\text { Gun turret lower quarters } \\
\text { Radar offices } \\
\text { Electrical spaces } \\
\text { Workshops } \\
\text { Sick bays } \\
\text { Communication offices } \\
\text { Galleys }\end{array}$ & $\begin{array}{l}28 \cdot 9 \\
31 \cdot 5 \\
30 \cdot 2 \\
30 \cdot 3 \\
30 \cdot 5 \\
32 \cdot 0 \\
30 \cdot 8 \\
28 \cdot 3 \\
29 \cdot 9 \\
30 \cdot 8\end{array}$ & $\begin{array}{l}32 \cdot 2 \\
39 \cdot 2 \\
35 \cdot 3 \\
33 \cdot 2 \\
36 \cdot 5 \\
40 \cdot 3 \\
37 \cdot 9 \\
32 \cdot 7 \\
35 \cdot 5 \\
36 \cdot 3\end{array}$ & $\begin{array}{l}27 \cdot 7 \\
31 \cdot 0 \\
29 \cdot 0 \\
29 \cdot 4 \\
28 \cdot 7 \\
28 \cdot 1 \\
28 \cdot 7 \\
27 \cdot 8 \\
28 \cdot 8 \\
29 \cdot 0\end{array}$ & $\begin{array}{r}100 \\
468 \\
172 \\
60 \\
160 \\
147 \\
193 \\
239 \\
163 \\
192\end{array}$ & $\begin{array}{r}947 \\
359 \\
364 \\
125 \\
59 \\
81 \\
55 \\
82 \\
168 \\
168\end{array}$ \\
\hline
\end{tabular}

TABLE 3

AVERAGE NORMAL EFFECTIVE TEMPERATURES AND CORRECTED EFFECTIVE TEMPERATURES SHOWING THE EFFECT OF "WILD HEAT"

\begin{tabular}{|c|c|c|c|c|}
\hline Compartment & $\begin{array}{l}\text { Normal } \\
\text { Effective Temperature } \\
\left({ }^{\circ} \mathbf{C} .\right)\end{array}$ & $\begin{array}{c}\text { Corrected } \\
\text { Effective Temperature } \\
\left({ }^{\circ} \mathrm{C} .\right)\end{array}$ & $\begin{array}{c}\text { Mean } \\
\text { Radiant Temperature } \\
\left({ }^{\circ} \mathbf{C} .\right)\end{array}$ & $\begin{array}{c}\text { No. of } \\
\text { Observations }\end{array}$ \\
\hline $\begin{array}{l}\text { Engine rooms } \\
\text { Boiler rooms } \\
\text { Gearing rooms } \\
\text { Electrical spaces } \\
\text { Galleys } \\
\text { Workshops } \\
\text { Radar offices } \\
\text { All observations }\end{array}$ & $\begin{array}{l}31 \cdot 4 \\
30 \cdot 2 \\
30.8 \\
31 \cdot 8 \\
30.6 \\
30 \cdot 8 \\
29.7 \\
30.8\end{array}$ & $\begin{array}{l}32 \cdot 4 \\
31 \cdot 0 \\
31 \cdot 8 \\
32 \cdot 4 \\
32 \cdot 2 \\
30 \cdot 7 \\
30 \cdot 3 \\
31 \cdot 7\end{array}$ & $\begin{array}{l}53 \cdot 9 \\
48 \cdot 7 \\
42 \cdot 4 \\
46 \cdot 0 \\
54 \cdot 4 \\
42 \cdot 0 \\
38 \cdot 1 \\
48 \cdot 2\end{array}$ & $\begin{array}{r}116 \\
59 \\
62 \\
50 \\
125 \\
36 \\
73 \\
519\end{array}$ \\
\hline
\end{tabular}

TABLE 4

'THE UPPER "TOLERABLE” LEVELS OF WARMTH CORRESPONDING TO A P4SR LEVEL OF 4.5 FOR MEN LIVING IN A TEMPERATE CLIMATE. BUT ACCLIMATIZED TO WORK AT HIGH TEMPERATURES EITHER AT WORK (100 kcal.//m. ${ }^{2} / \mathrm{hr}$.); OR AT REST ( $54 \mathrm{kcal} . / \mathrm{m} .{ }^{2} / \mathrm{hr}$.), FOR FOUR HOURS WEARING NAVAL OVERALLS; AS DERIVED FROM THE "P4SR" NOMOGRAM (MCARDLE et al., 1947)

\begin{tabular}{l|c|c|c|c|c|c|c|c|c|c|c}
\hline Dry-bulb temperature & ${ }^{\circ} \mathrm{C}$. & 33.8 & 35 & 37.7 & 40.5 & 43.7 & 46.1 & 48.8 & 51.6 & 54.4 \\
\hline $\begin{array}{l}\text { Corresponding wet-bulb temperature for } \\
\text { "working" men }\end{array}$ & ${ }^{\circ} \mathrm{C}$. & 32.5 & 32.4 & 32.3 & 32.1 & 31.9 & 31.8 & 30.2 & 27.3 & $*$ \\
\hline $\begin{array}{l}\text { Corresponding wet-bulb temperature for } \\
\text { "resting" men }\end{array}$ & ${ }^{\circ} \mathrm{C}$. & - & $*$ & 35.5 & 35.4 & 35.3 & 35.2 & 35.0 & 30.5 & 31.1 \\
\hline
\end{tabular}

Air speed $150 \mathrm{ft} . / \mathrm{min} .(76 \mathrm{~cm} . / \mathrm{sec}$.

* Outside range of nomogram.

TABLE 5

UPPER “TOLERABLE” EFFECTIVE TEMPERATURES $\left({ }^{\circ} \mathrm{C}\right.$.) CORRESPONDING TO A P4SR LEVEL OF 3 FOR MODERATELY ACTIVE (100 kcal./m. ${ }^{2} / \mathrm{hr}$.) ACCLIMATIZED YOUNG MEN DURING A FOUR-HOUR WATCH WEARING OVERALLS OR SHORTS*

\begin{tabular}{|c|c|c|c|c|c|c|c|c|}
\hline \multirow{3}{*}{$\begin{array}{c}\text { Mean } \\
\text { Air Speed } \\
\text { ft./min. (cm./sec.) }\end{array}$} & \multicolumn{4}{|c|}{ Men Wearing Overalls } & \multicolumn{4}{|c|}{ Men Wearing Shorts $\dagger$} \\
\hline & \multicolumn{4}{|c|}{ Dry-bulb Temperatures ${ }^{\circ} \mathrm{C}}$. & \multicolumn{4}{|c|}{ Dry-bulb Temperatures ${ }^{\circ} \mathrm{C}}$. \\
\hline & $32 \cdot 2$ & $37 \cdot 7$ & $43 \cdot 7$ & $48 \cdot 8$ & $32 \cdot 2$ & $37 \cdot 7$ & 43.7 & $48 \cdot 8$ \\
\hline $\begin{array}{c}20(10) \\
100(51) \\
300(152)\end{array}$ & $\begin{array}{l}30 \cdot 9 \\
31 \cdot 1 \\
-\end{array}$ & $\begin{array}{l}31 \cdot 5 \\
32 \cdot 1 \\
31 \cdot 7\end{array}$ & $\begin{array}{l}30 \cdot 65 \\
31 \cdot 3 \\
29 \cdot 3\end{array}$ & $\bar{z}$ & $\begin{array}{l}31 \cdot 6 \\
=\end{array}$ & $\begin{array}{l}32 \cdot 5 \\
33 \cdot 0 \\
32 \cdot 7\end{array}$ & $\begin{array}{l}32 \cdot 5 \\
33 \cdot 3 \\
32 \cdot 8\end{array}$ & $\bar{z}$ \\
\hline
\end{tabular}

* The observed energy cost of the same working routine was $111 \mathrm{kcal} . / \mathrm{m} .^{2} / \mathrm{hr}$. in London but only $100 \mathrm{kcal} . / \mathrm{m} .{ }^{2} / \mathrm{hr}$. in Singapore, a difference which has not been explained satisfactorily. The P4SR's here were calculated for $100 \mathrm{kcal} . / \mathrm{m} .{ }^{2} / \mathrm{hr}$., and would be slightly more for $111 \mathrm{kcal} . / \mathrm{m} .{ }^{2} \mathrm{hr}$.

t The higher basic effective temperatures for men wearing shorts emphasizes that the normal and basic scales are not interchangeable. 
bulb temperatures corresponding to this value are given in Table 4.

4. However, when allowance is made for all the variables which must be considered in a warship in time of war, and in particular for variations between individuals and for the fact that men are frequently neither naturally nor artificially acclimatized to the levels of warmth at which they may be called upon to work (Hellon, Jones, Macpherson, and Weiner, 1956; McArdle et al., 1947; Weiner and Macpherson, 1956), effective temperature levels which correspond to a P4SR value of 3 may be expected to cause incapacitating heat illness at times. Effective temperatures of this order, for men engaged in moderately active work wearing light or very light clothing are shown in Table 5 to be usually above $30^{\circ} \mathrm{C}$., but if the work were more strenuous or the clothing heavier or less permeable the limiting effective temperature would be appreciably lower in proportion to the additional stress imposed and might well be less than $30^{\circ} \mathrm{C}$. in certain circumstances.

The low value of $29.3^{\circ} \mathrm{C}$. is probably misleading and due to a constructional fault in the lower ranges of the P4SR nomogram.

5. The majority of acclimatized men living in ships or on shore in the tropics are reasonably comfortable in relation to their thermal environment provided the effective temperature does not exceed $25.5^{\circ} \mathrm{C}$. or fall below $22.8^{\circ} \mathrm{C}$. (Ellis, $1952 \mathrm{~b} ; 1953 \mathrm{c}$ ). In northern waters most men are reasonably comfortable by day and night when the air temperature is between 15.5 and $18.3^{\circ} \mathrm{C}$. (Pugh, 1949) as the Admiralty Ventilation Committee (1938) observed. This wide contrast with the tropical comfort zone is explainable in terms of the increased amount of clothing worn and differences in acclimatization.

6. Minor illnesses, particularly skin diseases, increase when the average monthly upper-deck temperature recorded at noon exceeds $26.7^{\circ} \mathrm{C}$. (Ellis, Smith, and Underwood, 1953; Smith, 1955) which corresponds approximately to effective temperatures on the mess decks of about $26.7^{\circ} \mathrm{C}$. Fig. 1 indicates the percentages of ships' companies who were on the "attending list" with minor disorders during the years 1948-1952 in relation to the average monthly upper-deck temperature as recorded at noon each day. Skin diseases contributed largely to the rise in ill-health with upper-deck temperatures above $26 \cdot 7^{\circ} \mathrm{C}$. There was no notable change at the cold end of the temperature scale.

7. We find that men living in warships in the tropics without air cooling for more than six months at a time under operational conditions (where we have seen that the average effective temperatures are

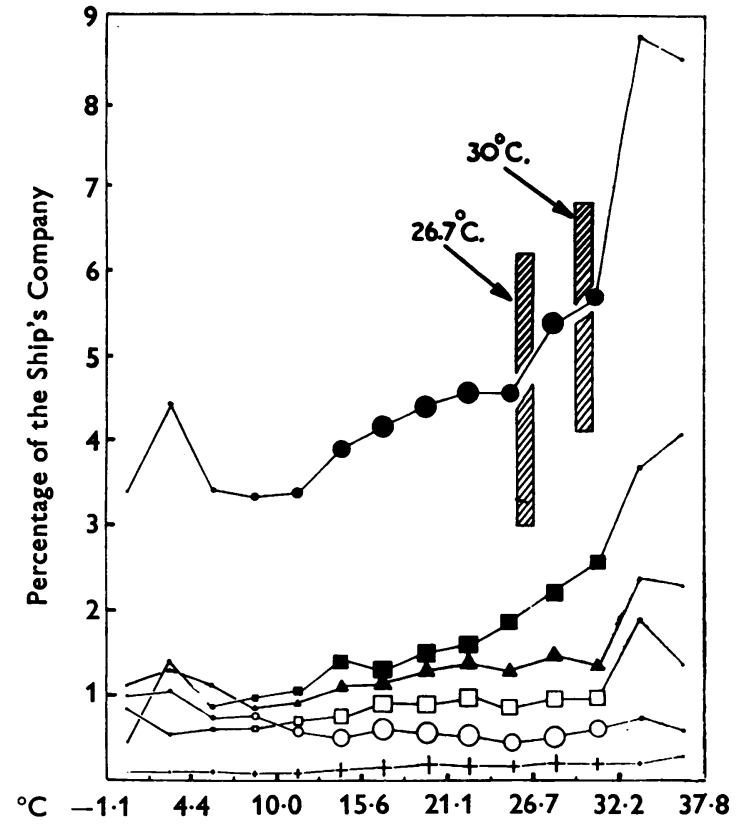

Mean Upper Deck Air Temperatures at Noon

Fig. 1.-Percentages of the ship's company on the attending list and the mean upper-deck air temperature at noon. (After Smith, 1958) total; $\square$ skin disease; $\square$ injuries; $O$ respiratory infection; + dysentery; $\Delta$ all other. (The area of each point plotted in the diagram is proportional to the number of monthly returns from which the average value was calculated.)

likely to be $28.9^{\circ} \mathrm{C}$. or higher (Table 2 ) are likely to develop symptoms of hot-climate or tropical fatigue (Ellis, 1952a, 1953b; Macpherson, 1949). This is typified by

"lethargy, mental retardation, reduced powers of concentration and sense of responsibility, irritability, and mild changes in personality and forgetfulness, which are associated often with excessive sweating, unsatisfactory sleep, skin disease, loss of weight, loss of appetite, and illdefined digestive disorders. This syndrome develops when men live and work at levels of warmth which result in the presence of unevaporated sweat on the skin and in the clothing or bedding. The majority of men exposed to these conditions will suffer in one way or another after a time, but in a healthy community serious breakdown will not be encountered very often, and there will be little reference to the condition in routine sickness returns. Most of these effects can be surmounted temporarily when it is necessary to make a special effort, and are relieved by resumption of life in a cooler climate" (Ellis, 1952a). 
Hot-climate fatigue can stand as a clinical entity on its own when encountered in an otherwise healthy community living and working in an excessively warm environment. It should be distinguished from the so called tropical neurasthenias, in the causation of some of which excessive warmth may play only a minor role, and from those conditions designated as heat exhaustion.

8. Thus the main finding, particularly from the studies on comfort, and sickness incidence, is that the upper desirable level of warmth to keep in mind in ship design for hot climates is an effective temperature of $25.5^{\circ} \mathrm{C}$. This is the Admiralty policy (Sims, 1945) and, it is believed, that of the United States Navy. Heating arrangements should be sufficient to provide air temperatures in living and working compartments between 15.5 and $18.3^{\circ} \mathrm{C}$. in northerly or southerly waters (Admiralty Ventilation Committee, 1938; Pugh, 1949). These figures in-
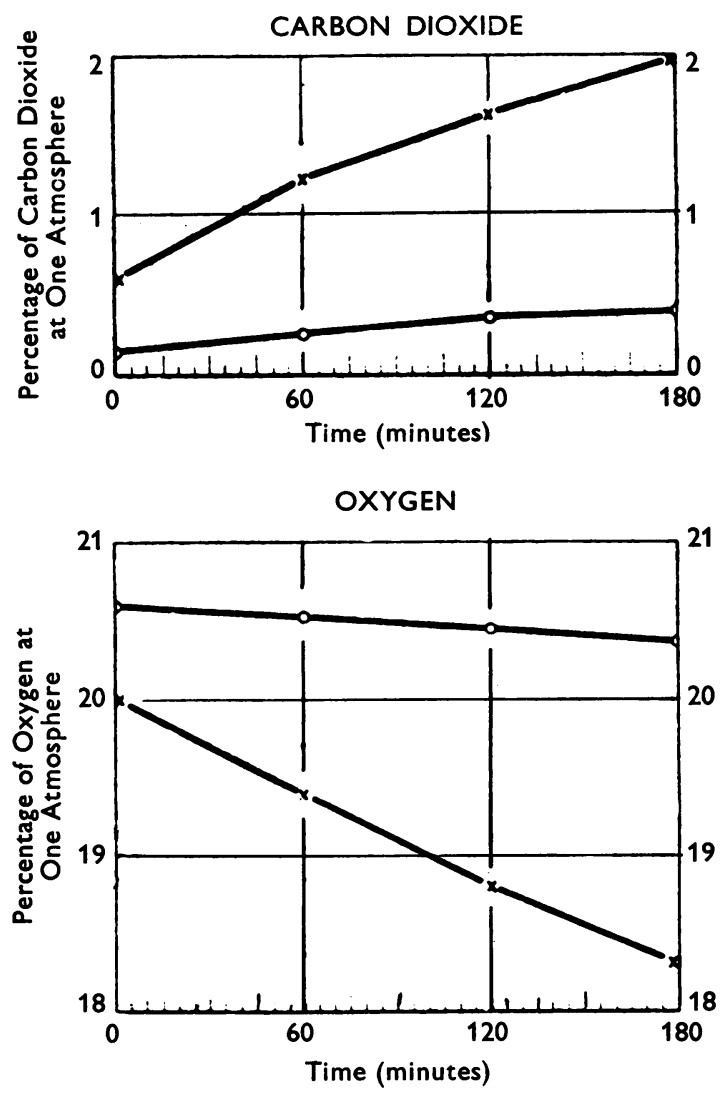

FIG. 2.-Carbon dioxide and oxygen content of the air in a sparsely occupied non-air-conditioned living space and in a crowded air-conditioned working space of a ship closed down. -x- working space; -o- living space. dicate the range to which we think the ship constructor should work.

It is not usually practicable to maintain effective temperatures between decks in the tropics below $25.5^{\circ} \mathrm{C}$., or in warm weather elsewhere when ships are closed down for action, unless the air is cooled and moisture extracted from it by a system which can only be operated economically when the spaces so treated are completely enclosed and carefully insulated to prevent them taking up heat from hot surroundings and when the fresh air supplies are restricted to the minimum compatible with health. These considerations have directed attention to associated effects on the chemical and bacterial constituents of the atmosphere and the permissible lower limits for fresh air requirements.

The manner in which oxygen decreases and carbon dioxide builds up is shown for a crowded working space and a sparsely occupied living space in a cruiser under closed-down conditions (Fig. 2). If the conditions in this working compartment were maintained for more than a few hours the fresh air supply would have to be re-established or equipment for releasing oxygen and removing carbon dioxide would have to be provided, unless the alternative of maintaining a fresh air supply, filtered to remove potentially harmful agents, were acceptable. In submarines, carbon dioxide levels may be in the region of $3 \%$ and mild anoxia may be unavoidable at the end of a long day's dive if nothing is done to restore the atmosphere. At levels of this order some men experience mild headaches and a disinclination for work and others may report "off-effects", nausea or vomiting, lassitude, and general malaise, on regaining the fresh air after surfacing, particularly if they are passengers who are unaccustomed to breathing air with a high carbon dioxide content.

The same effects are to be expected in air-conditioned compartments if the air is completely re-circulated without any fresh air dilution; this is also an added complication of closing down gunturret lower quarters completely for long periods. The oxygen depletion and carbon dioxide accumulation can be estimated approximately provided the size of the compartment and the number of occupants are known. A man doing light work requires $1.1 \mathrm{cu}$. ft. $\left(0.033 \mathrm{~m}^{3}\right)$ of oxygen and exhales about $1 \mathrm{cu}$. ft. $\left(0.03 \mathrm{~m}^{3}\right)$ of carbon dioxide per hour; with hard work these figures may be quadrupled. It is surprising how soon a crowded, enclosed compartment can become untenable for this reason alone.

Investigations of the bacterial content of the air in a cruiser and a submarine were carried out towards the end of the war (Ellis and Raymond, 1948). Counts of bacteria-carrying particles which exceeded $50 / \mathrm{cu}$. ft. $\left(1,760 / \mathrm{m}^{3}\right)$ were at that time 
considered undesirable by the air hygiene experts, and in most of the compartments of the cruiser this level was not exceeded, except when there was much activity on the mess decks. The air in the submarine was remarkably free from bacteria-carrying particles whether it was submerged or on the surface, probably because the particles adhered to the ventilation ducting or to oily surfaces. The microorganisms in the air samples were nearly all nonpathogenic, or of very low pathogenicity. However, the bacteria-carrying particle count does provide a ineasure of the micro-organism-carrying potential of the ventilation system, which can be greatly reduced by measures for eliminating dust and reducing the particle content of the air.

Tests undertaken for a few hours in an air-conditioned space in the cruiser and in a climate controlled room in London indicated that a build up of bacteria-carrying particles in the air did not occur even when the air was completely re-circulated, probably for similar reasons to those which controlled airborne particles in the submarine. A more recent study confirms this finding for complete re-circulation for periods of 24 hours. More extended trials are desirable.

The minimal supplies of fresh air which will permit men to live a comfortable, healthy, and efficient existence in an enclosed space are thus influenced by a variety of factors. Unrestricted heavy tobacco smoking causes malaise, headaches, and upper respiratory tract irritation. With air cooling, $5 \mathrm{cu}$. ft. $\left(0.15 \mathrm{~m}^{3}\right)$ of air per man per minute is sufficient to keep body and tobacco odours at acceptable levels (Consolazio and Pecora, 1946). With activated carbon filters and air cooling even $1 \mathrm{cu} . \mathrm{ft}$. $\left(0.03 \mathrm{~m} .{ }^{3}\right)$ per man per minute is adequate. In the United States Navy a fresh air supply of $5 \mathrm{cu}$. ft. $\left(0 \cdot 15 \mathrm{~m}^{3}\right)$ per man per minute is the minimum required by design for air-cooled compartments, although for other reasons, this amount is usually exceeded in practice. In the Royal Navy at least $10 \mathrm{cu} . \mathrm{ft} .\left(0 \cdot 3 \mathrm{~m} .{ }^{3}\right)$ per man per minute is supplied to air-cooled compartments when the cooling is in operation. For compartments with normal ventilation an allowance of $10 \mathrm{cu}$. $\mathrm{ft}$. $\left(0.3 \mathrm{~m}^{3}\right)$ per man per minute is added to the amount which is calculated to be necessary to get rid of the heat within the compartment. The total quantity must be equivalent to at least $30 \mathrm{cu}$. $\mathrm{ft} .\left(0 \cdot 9 \mathrm{~m} .^{3}\right)$ per man per minute (Admiralty, 1946).

There are, of course, some compartments which it is not possible to "air-cool" and which may become intensely warm when the ventilation system is closed down, such as certain machinery spaces. Reliance must then be placed either on air-ventilated or aircooled suits or cubicles, the design requirements of which are influenced by the duration and type of work which must be done, or on the alternative of relieving watchkeepers very frequently and within the period known to be endurable for the work, clothing, and temperature conditions imposed.

The most recent "enclosed space" which challenges the naval hygienist is the submarine powered with a nuclear reactor. Lieutenant Commander John H. Ebersole, Medical Officer of the United States Submarines, Nautilus and Seawolf, gave a fascinating glimpse, in an address to the Royal Society of Medicine in London in December 1957 (Ebersole, 1958), of the complex situation with which he and his technicians and the submarine designers have had to contend, and of the success their efforts have achieved. The remarkable control of the radiation environment and the completeness of his records for every man in the cre $N$ suggest that the United States Navy has already learnt the lesson of how to live all day and every day in the close vicinity of a powerful nuclear reactor with complete radiological safety, acquired as a result of careful training, a thorough understanding of the problem, constant vigilance ( 24 hours a day), and superlative engineering design. The 60 -day underwater cruise of the U.S.S. Seawolf has since been undertaken and the second instalment of this story is eagerly awaited.

Repeated submarine patrols, completely submerged for 60 days or more, are now a feasible proposition. It seems that only limitations imposed by human factors can stay the development of naval operations in this area. Many of the practical answers can only be obtained in the submarine. When a normal constituent of the atmosphere such as carbon dioxide, is present in abnormally high amounts, only time can indicate whether such effects as readjustment of the acid-base balance are acceptable adaptations or unacceptable effects which may be harmful. When gross atmospheric impurities, such as excess carbon dioxide or monoxide, are removed the possibility still remains that very prolonged and repeated exposure to minute traces in the air of volatile components or breakdown products of refrigerants, tobacco, fuels, lubricants, solvents, cooking fats, paints, plastics, or even of products of the human body itself, most of which in the past have usually been ignored, may in some way prove harmful.

There may be less tangible considerations. At the International Congress of Tropical Medicine at Lisbon in 1958 Professor C. D. de Langen of the Netherlands referred to the effects of variations in the electrical charge of the atmosphere on feelings of well-being and on the relative severity of the symptoms of climate-sensitive patients he had 
observed in the Netherlands' Indies many years ago (De Langen, 1934). Recent work in the United States and Russia also suggests that this factor may have to be taken into serious consideration by air hygiene experts.

The basic information which is needed to deal with the enclosed space of the submarine has, of course, applications elsewhere in the design of underground or underwater shelters, depots, control points, or headquarters, or, if one gazes more deeply into the crystal, in space ships or world satellites. These considerations go far beyond the single discipline of environmental hygiene. Environmental medicine is perhaps a better term to describe the very broad approach which is required.

It is concluded that, although much has been learnt about the naval environment and others like it since our forefathers first sailed east and west to the Indies, the demands today for accurate design data and information concerning the ways in which new environmental situations may affect those exposed to them are probably as heavy as they have ever been. There is still much more to be learnt.

This paper is published by permission of Surgeon Vice-Admiral Sir Cyril May, K.B.E., C.B., M.C., Q.H.S., F.R.C.S., Medical Director-General of the Navy, and of Major-General William H. Powell, Jr., United States Air Force (Medical Corps), Chief Medical Officer, Supreme Headquarters Allied Powers, Europe.

\section{REFERENCES}

Admiralty (1946). Book of Reference 1094 Admiralty Ventilation Committee Report (1914). H.M.S.O., London. - (1938). Unpublished.

Bedford, T. (1946). Med. Res. Coun. (Lond.), War Memo No. 17. Belding, H. S., and Hatch, T. F. (1955). Heat. Pip. Air Condit., 27, August, p. 129. Bernan, W. (1845). Art of Warming and Ventilating. George Bell,
London.
Clark-Kennedy, A. E. (1929). Stephen Hales. Cambridge Ưniversity Press, London.

Consolazio,'W. B., and Pecora, L. J. (1946). U.S. nav. med. Res. Inst. Project X-533 Ref. No. 4

Critchley, M. (1945). Brit. med. J., 2, 145, 173, 208.

De Langen, C. D. (1934). Malayan med. J., 9, 1.

Desaguliers, J. T. (1727). Phil. Trans., 35, 353.

- (1735). Ibid., 39, 41, 281.

Ebersole, J. H. (1958). Proc. roy. Soc. Med., 51, 63.

Ellis, F. P. (1947). Brit. med. Bull., 5, 13.

El1948). Brit. med. J., 1, 587.

- (1950). Med. J. Malaya, 4, 175

- (1952a). Lancet, 2, 527.

- (1952b). J. Hyg. (Lond.), 50, 415.

- (1953a). Ann. roy. Coll. Surg. Engl., 13, 369.

(1953b). Symposium on Fatigue. Ergonomic Research Society. Lewis, London.

Lewis, London.

J953c). Hyg. (Lond.), 51,
Brit. med. J., 2, 549.

(1955). Brit. med.J., 2, 2 ,

Ferres, H. M., Lind, A. R., and Newling, P. S. B. (1954). J. Physiol. (Lond.), 125, 55P.

and Raymond, W. F. (1948). Spec. Rep. Ser. med. Res. Coun. (Lond.), No. 262, p. 264.

—, Smith, F. E., and Underwood, C. R. (1953). Brit. J. prev. soc. Med., 7, 69.

Hales, S. (1755). Phil. Trans., 49, 332.

Hellon, R. F., Jones, R. M., Macpherson, R. K., and Weiner, J. S. (1956). J. Physiol. (Lond.), 132, 559

Houghten, F. C., and Yagloglou, C. P. (1923). Trans. Amer. Soc. Heat Vent. Engrs, 29, 163.

Irwin, J. O. (1956). Bbiometrics, 12, 475

McArdle, B., Dunham, W., Holling, H. E., Ladell, W. S. S., Scott, J. W., Thomson, M.' L., and Weiner, J. S. (1947). Med. Res. Coun. Royal Naval Personnel Research Committee, Med. Res. Coun. Report 47/391. Quoted by Smith, F. E. (1955)

Mackworth, N. H. (1950). Spec. Rep. Ser. med. Res. Coun. (Lond.),

(1948). ${ }^{268}$ Royal Society Empire Scientific Conference 1946, Report, Vol. 1, p. 423.

Macpherson, R. K. (1949). Tropical Fatigue. University of Queensland Papers.

Minard, D. (1958). Personal Communication.

Pepler, R. D. (1953 and 1954). Med. Res. Coun. (Lond.) R.N. Personnel Research Committee Reports 53/765, 54/793. Personnel Research Commics, 2, 63.
(1958). Ergonomics.

Pugh, L. G. C. (1949). Med. Res. Coun. Personnel Research Committee Report, 49/558.

Roberts, J. A. F.(1948). Brit. J. Prev. soc. Med., 2, 55

Shaw, T. B. (1929). Naval Hygiene. Humphrey Milford, London.

Sims, A. J. (1945). Trans. Instn nav. Archit. (Lond.), 87, 50

Smith, F. E. (1955). Mem. Med. Res. Coun. (Lond.), No. 29.

(1958). Brit. J. prev. soc. Med., 15, 197. United States Army (1957) Technical Bulletin, Medical 175. (Also
as U.S.N. NAVMED P-5052-5 and U.S.A.F. AFP 160-4-1)

Weiner, J. S., and Macpherson, R. K. (1956). 20 Int. Physiol Congress Rep., p. 874.

Yaglogou, C. P., and Miller, W. E. (1925). J. Amer. Soc. Heat Vent. Engrs, 31, 89. 